\title{
Management of Powdery Mildew Disease of Babchi (Psoralea corylifolia)
}

\author{
R. T. Gaikwad, B. Y. Pawar and S. R. Shinde* \\ AICRP on Medicinal, Aromatic Plants and Betelvine, \\ Mahatma Phule Krishi Vidyapeeth, Rahuri-413 722, India \\ *Corresponding author
}

\section{Ke y w o r ds \\ Powdery mildew disease, Babchi, Erysiphe cichoracearum \\ Article Info \\ Accepted: \\ 10 August 2020 Available Online: 10 September 2020}

\begin{abstract}
A B S T R A C T
The powdery mildew disease of Babchi (Psoralea corylifolia) caused by Erysiphe cichoracearum is a devastating disease results into complete defoliation of leaves due to severe infection, which hampers seed yield. Babchi a medicinal plant whose seeds are used in the treatment of leprosy, leucoderma, psoriasi and other skin diseases. Seed oil is recommended for application over scalps to treat dandruff. The plant extracts have been reported to posses antibacterial, antitumor, antioxidant, anti-inflammatory properties. Such a wonderful crop suffered from powdery mildew. Looking to the importance of this disease the field experiment was conducted during kharif 2017-18 for its management. The experiment was conducted with seven treatments which were replicated thrice in a randomized block design. The treatments were $\mathrm{T}_{1^{-}}$Spraying of salicylic acid @ $100 \mathrm{ppm}, \mathrm{T}_{2^{-}}$ Spraying of butter milk@5 ml/litre, $\mathrm{T}_{3}$ - Spraying of mineral @ $10 \mathrm{ml} /$ litre, $\mathrm{T}_{4}$ - Spraying of yeast Ampelomyces quisqualis @ 5 g/litre, $\mathrm{T}_{5^{-}}$Spraying of Baking soda @ 2 g/litre, $\mathrm{T}_{6^{-}}$Spraying of wetable sulphur@ $2.5 \mathrm{~g} /$ litre and $\mathrm{T}_{7^{-}}$Untreated control. The sprayings were undertaken as soon as the powdery mildew disease was noticed on few plants, overall three sprays were taken at an interval of 15 days. The results indicated that all the treatments significantly recorded lowest powdery mildew intensity and maximum seed yield as compared to untreated control. The lowest powdery mildew intensity $29.68 \%$ was observed in treatment $\mathrm{T}_{6}$ i.e. spraying of wetable sulphur with maximum reduction $60.33 \%$ of powdery mildew and highest seed yield $17.75 \mathrm{q} / \mathrm{ha}$. However, the treatment $\mathrm{T}_{4}$ i.e. spraying Ampelomyces was statistically on par with the treatment of wetable sulphur for both the characters i.e. powdery mildew intensity $(23.63 \%)$ and seed yield $(17.36 \mathrm{q} / \mathrm{ha})$. The results obtained from present investigation concluded that three sprayings of wetable sulphur @ $2.5 \mathrm{~g} / \mathrm{lit}$. or yeast i.e. Ampelomyces quisqualis @ $5 \mathrm{~g} / \mathrm{lit}$. was found to most effective for the management of powdery mildew of Babchi crop.
\end{abstract}

\section{Introduction}

Babchi (Psoralea corylifolia) a medicinal plant belongs to family Fabaceae. It's distribution is found in semi-arid region of Rajasthan and Eastern districts of Punjab and adjoin Uttar Pradesh. The seeds of the plant contain variety of coumarins including psoralen. The seeds are used in the treatment of leprosy, leucoderma, psoriasis and other skin diseases. Seed oil is recommended for application over scalp to treat dandruff. The plant extracts have been reported to posses antibacterial, antitumer, antioxidant, antiinflammatory, antifungal and immunomodulatory properties. Such wonderful crop is severely suffering from the powdery mildew disease caused by Erysiphe cichoracearum. 


\section{Materials and Methods}

Powdery mildew is a devastating foliar disease of Babchi and for its management a field experiment was taken during 2017-18 at AICRP on Medicinal, Aromatic Plants \& Betelvine, Mahatma Phule Krishi Vidyapeeth, Rahuri (M.S.). There were seven treatments which were replicated three times in Randomized Block Design (RBD). The treatments consist of spraying of salicylic acid @100 ppm, butter milk@5 ml/lit, mineral oil@10 ml/lit, yeast - Ampelomyces quisqualis@5 g/lit, baking soda@2 g/lit, wettablesulphur@2.5 g /lit and untreated control. Overall three sprayings were given as soon as the powdery mildew symptoms observed on few plants at an interval of 15 days.

\section{Results and Discussion}

The data presented in Table 1 in respect of powdery mildew and seed yield ( $\mathrm{q} / \mathrm{ha}$ ) indicated that all the treatments recorded lowest powdery mildew intensity and maximum seed yield as compared to the control. The lowest powdery mildew intensity $29.68 \%$ was observed in the spraying of wettable sulphur $\left(\mathrm{T}_{6}\right)$ with maximum reduction $60.33 \%$ of powdery mildew and highest seed yield of $17.75 \mathrm{q} / \mathrm{ha}$. However, spraying of yeast i.e. Ampelomyces quisqualis was statistically on par with wettable sulphur for both the characters i. e. powdery mildew intensity (33.63\%) and seed yield (17.36 q/ha).

Table.1 Effect of different treatments on intensity of powdery mildew disease and seed yield of babchi

\begin{tabular}{|c|l|c|c|c|c|}
\hline $\begin{array}{c}\text { Treat. } \\
\text { No. }\end{array}$ & Treatment details & $\begin{array}{c}\text { Powdery } \\
\text { mildew } \\
\text { intensity } \mathbf{( \% )}\end{array}$ & PDC & $\begin{array}{c}\text { Seed yield } \\
(\mathbf{q} / \mathbf{h a})\end{array}$ & $\begin{array}{c}\text { Per cent seed } \\
\text { yield increased } \\
\text { over control }\end{array}$ \\
\hline $\mathbf{T}_{\mathbf{1}}$ & $\begin{array}{l}\text { Spraying of Salicylic } \\
\text { acid @ 100 ppm }\end{array}$ & $\begin{array}{c}37.18 \\
(37.57)\end{array}$ & 50.30 & 15.15 & $\mathbf{6 1 . 3 4}$ \\
\hline $\mathbf{T}_{\mathbf{2}}$ & $\begin{array}{l}\text { Spraying of Butter } \\
\text { milk @ 5 ml/lit }\end{array}$ & $\begin{array}{c}38.07 \\
(38.10)\end{array}$ & 49.11 & 12.71 & $\mathbf{3 5 . 3 6}$ \\
\hline $\mathbf{T}_{\mathbf{3}}$ & $\begin{array}{l}\text { Spraying of mineral } \\
\text { oil @ 10 ml/lit }\end{array}$ & $\begin{array}{c}36.00 \\
(36.87)\end{array}$ & 51.88 & 16.03 & $\mathbf{7 0 . 7 1}$ \\
\hline $\mathbf{T}_{\mathbf{4}}$ & $\begin{array}{l}\text { Spraying of } \\
\text { Amploymces @ 5 ml } \\
\text { /lit }\end{array}$ & $\begin{array}{c}33.63 \\
(35.44)\end{array}$ & 55.05 & 17.36 & $\mathbf{8 4 . 8 8}$ \\
\hline $\mathbf{T}_{\mathbf{5}}$ & $\begin{array}{l}\text { Spraying of baking } \\
\text { soda @ 2 g/lit }\end{array}$ & $\begin{array}{c}41.60 \\
(40.16)\end{array}$ & 44.39 & 11.62 & $\mathbf{2 3 . 7 5}$ \\
\hline $\mathbf{T}_{\mathbf{6}}$ & $\begin{array}{l}\text { Spraying of wetable } \\
\text { sulphur @ 2.5 g/lit }\end{array}$ & $\begin{array}{c}29.68 \\
(33.01)\end{array}$ & 60.33 & 17.75 & $\mathbf{8 9 . 0 3}$ \\
\hline $\mathbf{T}_{\mathbf{7}}$ & Control (Water spray) & $\begin{array}{c}74.81 \\
(59.87)\end{array}$ & - & 9.39 & - \\
\hline & S.E. \pm & 1.57 & - & 0.42 & - \\
\hline & CD at 5 \% & $\mathbf{4 . 8 3}$ & - & $\mathbf{1 . 4 2}$ & - \\
\hline
\end{tabular}

Figures in parenthesis are arc-sine values to which statistical analysis pertains 

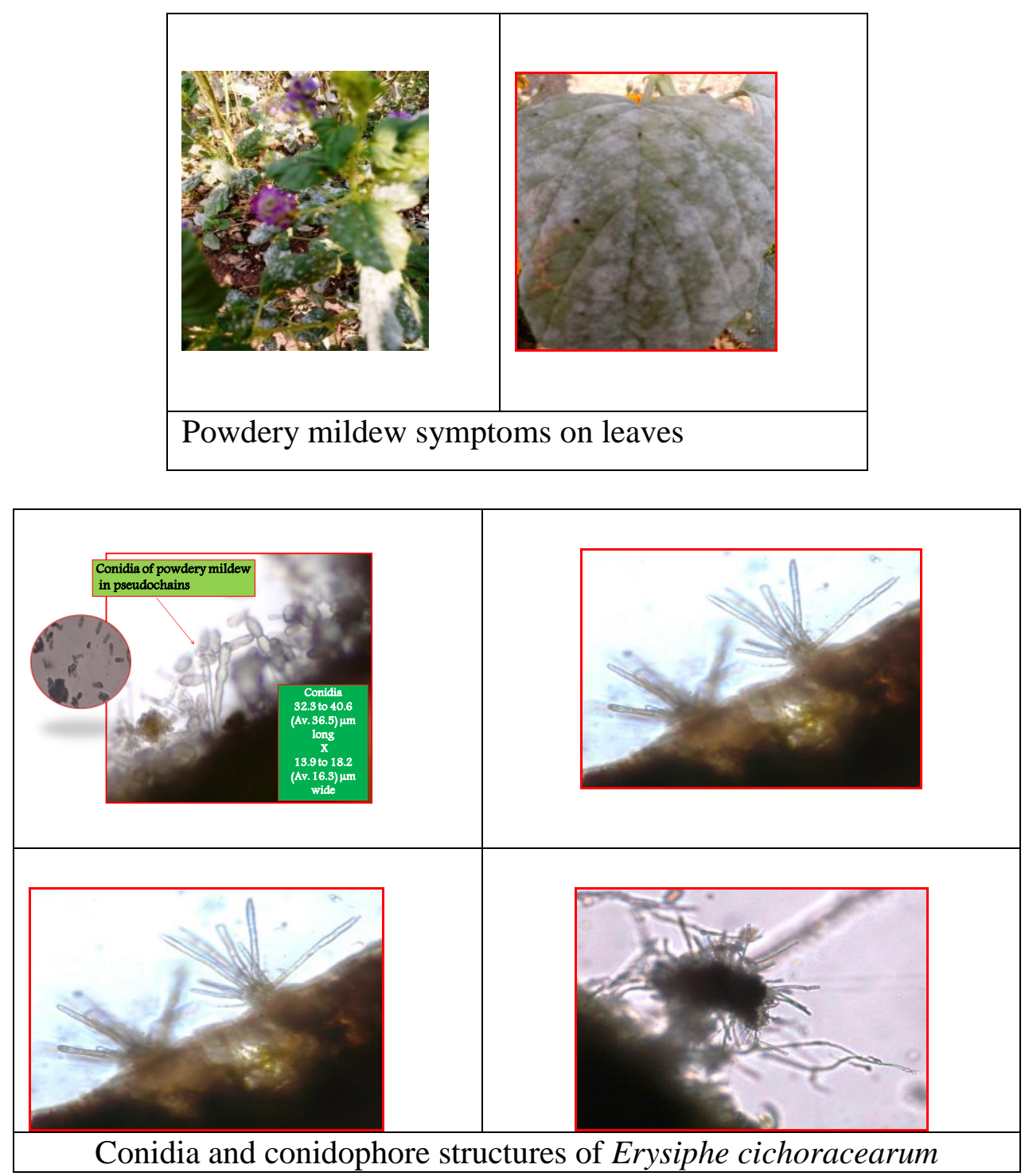

Ampelomyces quisqualis is a specific mycoparasite of Erysiphales, with no impact on human health and environment. It is the most studied biocontrol agent of powdery mildews and one strain isolated in Israel (CNCM I-807) has been commercialized in several countries (Maurhofer, 2013). Dhruj et al., (2000) reported that tridemorph, dinocarp and wettable sulfur were moderately effective, where $30.77,30.88,31.88 \%$ disease intensity and 1863, 1844, $1891 \mathrm{~kg} / \mathrm{ha}$. Seed yield were recorded, respectively.

It was concluded that spraying of wettable sulphur @2.5g/lit. or yeast Ampelomyces quisqualis @ 5ml/lit. was found to be effective for the management of powdery mildew disease of Babchi.

\section{References}

Anonumous (2018). Annual report 2017-18, All India Co-ordinated Research Project on Medicinal, Aromatic Plants and Betelvine.

Anonymous (2017) Annual report 2017-18, ICAR- Directorate of Medicinal and Aromatic Plants Research, Boroavi, 
Anand, Gujarat.

Monika Maurhofer, llaria Pertot, Krishna Saharan and D. Angeli (2013). Increasing efficacy of Ampelomyces quisqualis against powdery mildew. Phytopathology.
Dhruj I.U., Akbari L.E., Khandar R.R. and Jadeja B. (2000). Field evaluation of fungicides against powdery mildew of Fenugreek. J. of Mycology and Plant Pathology. 30(1): 98-99.

\section{How to cite this article:}

Gaikwad, R.T., B.Y. Pawar and Shinde, S.R. 2020. Management of Powdery Mildew Disease of Babchi (Psoralea corylifolia). Int.J.Curr.Microbiol.App.Sci. 9(09): 1047-1050.

doi: https://doi.org/10.20546/ijcmas.2020.909.130 